\title{
Realities of ambulatory multi-drug treatment of chronic diseases in rural areas of Lublin Province, eastern Poland - comparison of situations in 2010 and 2013
}

\author{
Barbara Kołłątaj', Irena Dorota Karwat ${ }^{1}$, Witold Kołłątaj ${ }^{2}$, Katarzyna Sygit ${ }^{3}$, Marian Sygit ${ }^{4}$ \\ ${ }^{1}$ Chair and Department of Epidemiology, Medical University, Lublin, Poland \\ ${ }^{2}$ Department of Paediatric Endocrinology and Diabetology, Medical University, Lublin, Poland \\ ${ }^{3}$ Department of Health Promotion, Faculty of Physical Education and Health Promotion, University of Szczecin, Poland \\ ${ }^{4}$ Department of Health Education, Faculty of Physical Education and Health Promotion, University of Szczecin, Poland \\ Kołłątaj B, Karwat ID, Kołłątaj W, Sygit K, Sygit M. Realities of ambulatory multi-drug treatment of chronic diseases in rural areas of Lublin \\ Province, eastern Poland - comparison of situations in 2010 and 2013. Ann Agric Environ Med. 2015; 22(3): 530-535. doi: 10.5604/12321966.1167729
}

\begin{abstract}
Introduction. The economic stratification observed for many years among the population in Poland, increasing poverty rates, especially those being effects of the current economic crisis in the country, and the rising prices of medicines, are potential risk factors for medication non-adherence among patients in the poorest class of the Polish population.

Materials an method. The subjects were 2 groups of inhabitants of rural areas of Lublin Province in eastern Poland. The first consisted of 209 people aged 52-80 years who were surveyed in 2010, the second - 210 people aged 51-88 years, surveyed in 2013. All patients were outpatients who attended the Endocrine Clinic in Poniatowa. The studies were conducted with the use of the standardized survey questionnaire.

Results. The problem of medication non-adherence among the surveyed was evident and has risen from $43.1 \%$ in 2010 to $54.8 \%$ in 2013. Both in 2010 and in 2013, the main reasons for this state of affairs were the financial problems of the surveyed people. During the period 2010-2013, both expenditure on medicine as well as the ratio "patients' expenditure on medicine/ expenditure on food" had increased. In 2010, 25 respondents per 209 (12\%) expressed the opinion that they had always had sufficient means to buy necessary medications, in 2013 - only 3 per 210 (1.5\%).

Conclusions. In 2013, most of surveyed patients (54.8\%) did not follow prescribed treatment plans (in 2010-43.1\%). In most cases, medication non-adherence were the result of financial problems. Current regulations governing refunding of the costs of medicines may make effective ambulatory treatment of chronic diseases impossible.
\end{abstract}

- Key words

rural areas, chronic diseases, ambulatory treatment, poverty, medication non-adherence

\section{INTRODUCTION}

Medication non-adherence is recognized as being a problem common worldwide. It encompasses behaviours, both intentional and unintentional, that lead either to underuse or over-use of prescription medications. The over-use includes: taking higher than recommended doses, taking medication prescribed for someone else, or applying longer than recommended treatment. The under-use of medications includes a wide range of behaviours such as: delay in filling a prescription, not filling a prescription, not picking up a prescription, not refilling a prescription, skipping doses (omitting one or multiple doses), splitting pills, stopping a medication early, taking a dose at an incorrect time, taking medications with prohibited foods, liquids, or other medications, taking medications that have expired, are damaged, or improperly stored, improper use of medication devices (e.g. inhalers, syringes), and reducing doses.

Factors contributing to poor medication adherence are related to patients and physicians, as well as health care

Address for correspondence: Witold Kołłątaj, Chair and Department of Epidemiology, Medical University, Chodźki 2, 20-093 Lublin, Poland

E-mail:wk@data.pl

Received: 03 September 2013; accepted: 05 February 2015 systems. The WHO classifies these factors into 5 categories: socio-economic, factors associated with the health care team and system in place, disease-related factors, therapy-related factors, and patient-related factors [1]. The impact of the above-mentioned factors on the phenomenon of medication non-adherence may vary in different countries, and depends on the development of the country, the state of well-being of society, and the age structure of the population.

In better developed countries this problem concerns mainly the groups of elderly people who typically require long-term, if not lifelong, medications to control symptoms and prevent complications. Such new, every-day duties can be difficult to integrate into everyday life, especially when patients suffer from mental problems, loss of memory or cognitive impairment. The fact of a fairly widespread fear of long-term multi-drugs therapies is not without significance. Older patients may deliberately choose not to adhere to medication (intentional non-adherence) to avoid adverse effects, many of them (those with mental problems, loss of memory and cognitive impairment) are not able to understand and remember regimens of prescribed therapies. Such attitudes and negligence may be named as patientdependent, or related to patients.

In low- and middle-income (LAMI) countries, the problem of inadequate treatment is tightly connected with poverty and 
reduced access to health care [1]. The causes of medication non-adherence are often not intentional, but due to of the lack of funds to pay for medical services (i.e. paid drug injections) and for the purchase of medicines. Finances may be a barrier to adherence, especially for senior citizens on a fixed income.

Medication non-adherence is a major public health problem that has been called an 'invisible epidemic'. Adherence to long-term therapy for chronic illnesses in developed countries averages was close to $50 \%$ in 2003 [1], in people aged 60 years or older, rates of adherence to medication regimens ranged from $41 \%$ - 74\% [2].

Data concerning the situation in LAMI countries are incomplete; for example, the adherence to medications in diabetic patients in rural Kerala, India, was close to $26 \%$ in 2012 (prevalence of poor adherence - 74\% [3]), 43.2\% in Kenya in 2009, anti-retroviral drug therapy by adult patients attending HIV/AIDS clinic at a Kenyan tertiary health institution [4]), 41.7\% in rural El-Mina, Egypt in 2011[5], 45.5\% in Pakistan (not supervised outpatients with schizophrenia (data obtained in 2011) [6], and $40 \%$ in Columbia (survivors of strokes and transient ischemic attacks; data published in 2013) [7].

Non-adherence to pharmacotherapy decreases productivity, increase diseases morbidities and deaths. It also influences on increment of physician office visits, admissions to nursing homes, and generally on costs associated with the functioning of health care and social services. It has been estimated that non-adherence to prescribed medications causes, in USA, nearly125,000 deaths [8] (data published in 2005 ) and costs $\$ 2,000$ per patient in physician visits annually [9]. There are suggestions that medication non-adherence results in: 5.4 times increased risk of hospitalization, rehospitalization, or premature death for patients with high blood pressure, 2.5 times increased risk of hospitalization for patients with diabetes [10], and more than 1.4 times increased nursing home admissions [10]. Some authorities suggests that improving medication adherence has the potential for a greater impact on the health of the population than improvements in medical therapy.

The economic stratification of the population observed for many years in Poland, increasing poverty rates, especially those being effects of the current economic crisis in the country, and the rising prices of medicines are potential risk factors for medication non-adherence among patients coming from the poorest class of the Polish population. The scale of such an important multi-dimensional problem is still undetermined. In Poland, the least prosperous regions are as follows: Lublin and Podkarpackie Provinces, where in 2011 there was noticed the highest proportions of families living in poverty and a high unemployment rate (in Lublin Province, the percentage of registered unemployed was equal to 14.1 , while in Poland the average value was close to 13.4 (December 2012) [11]. In 2011, the average monthly disposable personal income in the Lublin Province was equal to 1,055.4 PLN (currency - Polish Zloty) [12], while the average monthly disposable personal income in Poland was almost 20.5\% higher, amounting to 1,270 PLN [12]. In Poland, poverty mostly affects little-industrialized areas such as rural districts. One of the poorest areas in the Lublin Province (with the lowest median household income) is the area including Opole Lublelskie, Poniatowa and Chodel districts.

Analysis of health care status quo in such districts could be a good idea for assessment of the real consequences both reforms initiated in 1999 and the worsening of economic situation of the country. It should make health care decisionmakers aware of the danger threats to other regions of the country at a time when economic forecasts for Poland are still not optimistic.

\section{MATERIAL AND METHODS}

The material for this study consisted of 2 groups of inhabitants of the rural areas of Opole Lubelskie, Poniatowa and Chodel districts in Lublin Province. These were outpatients who attended the Endocrine Clinic in Poniatowa, and due to the presence of co-morbid medical conditions required multidrug therapies - long-term multi-disciplinary treatment because of endocrine, cardiac, and quite often orthopaedic and gastrological as well as rheumatologic reasons.

The first group (G_2010) - people being surveyed in 2010 [13], the second (G_2013) - in 2013. The first group consisted of 209 people aged $52-80$ years (mean 63.5, SD 6.32), the second -210 people aged $51-88$ years (mean 62.52, SD 9.58). (Tab. 1).

Table 1. Survey respondents groups characteristics

\begin{tabular}{lcc}
\hline & \multicolumn{2}{c}{ Groups } \\
\hline Group characteristics & G_2010 [13] & G_2013 \\
\hline Survey periods & $\begin{array}{c}\text { December 2009- } \\
\text { April 2010 }\end{array}$ & $\begin{array}{c}\text { February 2013 - } \\
\text { April 2013 }\end{array}$ \\
\hline Group size (n) & 209 & 210 \\
\hline Age (y) & $63.5 \pm 6.32$ & $62.7 \pm 9.62$ \\
\hline Gender & & \\
$\quad$ Male (n;[\%]) & $60 ;(32.9)$ & $69 ;(32.8)$ \\
$\quad$ Female (n; [\%]) & $149 ;(67.1)$ & $141 ;(67.2)$ \\
\hline Regular income & & \\
a Yes (pensioners and people & & $196 ;(93.3)$ \\
$\quad$ professionally active) $(\mathrm{n} ;$ [\%]) & $192 ;(91.9)$ & $14 ;(6.7)$ \\
b No (unemployed) $(\mathrm{n} ;$ [\%]) & $17 ;(8.1)$ & \\
\hline
\end{tabular}

The data shown in table 1 suggest that the groups were almost the same.

The similarities concerned: both the number, age, gender (Chi-square: 0.846; p-value:0.358) [14], as well as the access to sources of regular income (Yates' Chi-square: 0.129; Yates p-value: 0.719).

A special original standardized survey questionnaire with questions concerning details of ambulatory treatment of chronic diseases, as well as details of the household budget, including sources of income and expenses structure, including expenses related to treatment, was applied. The questionnaire contained 15 closed-ended questions, among them:

- one-choice questions concerning age, education, residence, household conditions and household budget, sources of income, applied therapy and the cost of monthly treatment; - multiple-choice questions concerning the causes and essences of medical recommendations negligence, domestic spending priorities, and ways of reducing expenditure in the event of financial resources deficits.

The survey was carried out twice: during the period February 2013 - April 2013 (group G - 2013), and December 2009 - April 2010 (group G - 2010). It was based on survey 
feedback issued during a visit in the outpatient Endocrine Clinic and received during a subsequent visit to the Clinic.

Statistical methods. Most of the obtained data were grouped data, among them those which concerned money spent on medications, household expenses and food outlays (Tab. 5-7). Grouped data statistics were used to estimate:

- mode values (observation with the maximum frequency) defined as in the presented below algebraic expression:

- $\operatorname{mode}=L+\frac{(F-F 1)}{(F-F 1)+(F-F 2)} \times h$

where:

$\mathrm{L}=$ lower limit of the modal class $\mathrm{F}=$ frequency of the modal class $\mathrm{F} 1=$ frequency of the class immediate previous of modal class $\mathrm{F} 2$ = frequency of the class immediate next of modal class $h=$ range of the modal class (higher limit - lower limit)

- median values (preceded by identifying median classes); the medians were calculated by the following formula: median $=L+\left(\frac{\frac{n}{2}-c f}{F}\right) \times h$

where:

$\mathrm{n}=$ the number of observations

$\mathrm{L}=$ lower limit of median class

$\mathrm{cf}=$ cumulative frequency of class prior to median class

$\mathrm{F}=$ frequency of median class

$\mathrm{h}=$ class size (higher limit - lower limit).

This method was were used to calculate the data listed in Tables 8-10. Other statistics were performed with the use of licensed Statistica 10 software package and the interactive calculation tool for Chi-square tests of goodness of fit and independence [14].

\section{RESULTS}

Medication non-adherence - scope of the problem, forms and reasons. The problem of medication non-adherence can be noticed during analysing data obtained both in 2010 and 2013. In 2010 (group G - 2010), it concerned 90 (43.1\%) surveyed respondents, in 2013 (Group - 2013) - 115 (54.8\%) respondents. While comparing such data, the following conclusions can be drawn:

- the number as well as percentage of patients taking medicines inconsistently with the recommendations of doctors have increased;

- the mentioned increment is statistically significant (Chisquare: 5.738 ; p-value: $0.0166 ; \alpha=0.05$ ).

Such medication non-adherences are unfavourable both for patients and for the health care system. The phenomenon of medication non-adherences, on the one hand, reduce the chances of successful treatment, and on the other hand, means an obvious waste of financial resources allotted for the refunding of drugs. To counter such negative trends, one needs to understand their forms and reasons.

The scope of the problem of medication non-adherence among the surveyed adults (answers to multi-choice question) are present in Table 2, the reasons (refereed by respondents) are given in Table 3.
Table 2. Forms of medication non-adherence (answers to multi-choice question)

\begin{tabular}{lcc}
\hline & \multicolumn{2}{c}{ Groups } \\
\hline Forms of medication non-adherence & G_2010 & G_2013 \\
\hline taking only some of the recommended medications & $33.3 \%$ & $27.8 \%$ \\
\hline application of smaller, than recommended, doses & $22.2 \%$ & $8.7 \%$ \\
\hline periodic treatment interruptions & $15.5 \%$ & $15.6 \%$ \\
\hline taking medications in irregular way & $13.3 \%$ & $20 \%$ \\
\hline preferring longer, than recommended, dose intervals & $10.0 \%$ & $20.0 \%$ \\
\hline \begin{tabular}{l} 
application of higher, than recommended, doses of drugs \\
\hline other negligence (such as taking a drug at a different times of
\end{tabular} & $5.6 \%$ & $0.0 \%$ \\
\hline \begin{tabular}{l} 
the day, then recommended by the doctor) \\
\hline
\end{tabular} & $15.7 \%$ \\
\hline
\end{tabular}

Table 3. Reasons for taking medicines inconsistently with the recommendations of doctors

\begin{tabular}{lcc}
\hline & \multicolumn{2}{c}{ Groups } \\
\hline Reasons for medication non-adherence & G_2010 & G_2013 \\
\hline lack of money & $75.5 \%$ & $79.1 \%$ \\
\hline fear of side effects of such therapies & $40.9 \%$ & $9.6 \%$ \\
\hline fear of potential hazards of applied therapies & $26.7 \%$ & $7.0 \%$ \\
\hline too much drugs & $16.6 \%$ & $2.6 \%$ \\
\hline forgetting to take drugs & $10.0 \%$ & $17.4 \%$ \\
\hline lack of prescriptions & $5.6 \%$ & $6.1 \%$ \\
\hline
\end{tabular}

Both in 2013 and 2010, the main reasons for this state of affairs were caused by the financial problems of the surveyed people. In 2010, $75.5 \%$ of respondents explained medication non-adherence by economic problems (poverty and the consequent lack of financial resources to purchase drugs). In 2013, such opinions were reported by $79.1 \%$ of the surveyed. The differences between such percentages were not considered to be statistically significant (Chi-square: 0.371; p-value 0.5425; $a=0.05)$. In 2010, 25 respondents per 209 (12\%) expressed the opinion that they had always possessed enough means to buy necessary drugs; in 2013 - only 3 per 210 (1.5\%); the differences are significant (Yates Chi-square: 16.986; $p$-value $0.00004 ; a=0.05$ ). Because of the fact that the deficiency of financial resources to purchase drugs was the main reason for medication non-adherence reported by those surveyed, the possible treatment modifications due to lack of funds have been analysed (Tab. 4).

Table 4. Ambulatory temporary treatment modifications due to periodic financial troubles

\begin{tabular}{llc}
\hline & \multicolumn{2}{c}{ Groups } \\
\hline $\begin{array}{l}\text { Proceedings in the case of the lack of funds to purchase } \\
\text { drugs }\end{array}$ & G_2010 & G_2013 \\
\hline - temporary cessation of treatment & $28.3 \%$ & $26.6 \%$ \\
\hline - borrowing money & $16.8 \%$ & $27.1 \%$ \\
\hline $\begin{array}{l}\text { - buying only these prescribed drugs which were the } \\
\text { cheapest ones }\end{array}$ & $16.8 \%$ & $14.5 \%$ \\
\hline $\begin{array}{l}\text { - other modifications such as temporary reduction of the } \\
\text { number of medications or doses prescribed by physicians }\end{array}$ & $13.6 \%$ & $12.1 \%$ \\
\hline $\begin{array}{l}\text { - buying cheaper generic drugs without any consultations of } \\
\text { this decision with doctors }\end{array}$ & $12.5 \%$ & $11.1 \%$ \\
\hline $\begin{array}{l}\text { - buying only those prescribed drugs which were considered } \\
\text { by survey respondents as the most important }\end{array}$ & $12 \%$ & $8.7 \%$ \\
\hline
\end{tabular}


Table 5. Monthly medication costs per person

\begin{tabular}{|c|c|c|c|c|c|c|c|c|c|c|}
\hline Group & Class interval (PLN) & $50-100$ & $101-150$ & $151-200$ & $201-250$ & $251-300$ & $301-350$ & $351-400$ & $401-450$ & $451-500$ \\
\hline \multirow{5}{*}{ G_2010 } & Frequency (F) & 52 & 64 & 62 & 9 & 21 & 1 & 0 & 0 & 0 \\
\hline & Frequency - Percent (\%) & 24.9 & 30.6 & 29.7 & 4.3 & 10.0 & 0.5 & & & \\
\hline & Cumulative frequency (cf) & 52 & 116 & 178 & 187 & 208 & 209 & & & \\
\hline & Median class interval - median & & 141.0 & & & & & & & \\
\hline & Modal class interval - mode $(*)$ & & 142.9 & & & 269.8 & & & & \\
\hline & Frequency - Percent (\%) & 19.0 & 17.6 & 17.1 & 13.8 & 21.9 & 2.9 & 4.8 & 1.4 & 1.4 \\
\hline G_2013 & Cumulative frequency (cf) & 40 & 77 & 113 & 142 & 188 & 194 & 204 & 207 & 210 \\
\hline & Median class interval - median & & & 163.4 & & & & & & \\
\hline & Modal class interval - mode $(*)$ & 96.5 & & & & 265.9 & & & & \\
\hline
\end{tabular}

(*) bimodal distribution

Lack of funds is a problem that influences the possibilities for successful multi-drug therapies. Poverty and periodic financial troubles are temptations to economize on medicines. The data in Table 4 suggest that $72.9 \%$ of patients having financial troubles save on treatment. Only $27.1 \%$ of people suffering from the lack of money try to borrow money to buy medications (in 2010-16.8\%) - the difference is statistically significant (Chi-square: 6.607; p-value 0.010; $\alpha=0.05$ ). Patients can find different ways to economize on treatment; among them, temporary cessation of treatment, buying generic instead prescribed drugs, or modifying therapies.

The most popular method that makes economizing on drugs possible is the temporary cessation of treatment (in $2013-26.6 \%$ of those with financial problems, in 2010-28.3, economized in this way) - the difference is not statistically significant.

The problem of improper ambulatory treatment realized by people must be analysed in context of their financial status and their expenditures both on medications as well as on food and housing. The structures of the monthly expenditures of the survey respondents in groups G1 and G2 are shown in Tables 5, 6 and 7 .

Table 6. Monthly food expenses per person

\begin{tabular}{|c|c|c|c|c|c|c|c|c|}
\hline Group & Class interval (PLN) & $\begin{array}{c}100- \\
150\end{array}$ & $\begin{array}{c}151- \\
200\end{array}$ & $\begin{array}{c}201- \\
250\end{array}$ & $\begin{array}{c}251- \\
300\end{array}$ & $\begin{array}{c}301- \\
350\end{array}$ & $\begin{array}{c}351- \\
400\end{array}$ & $>400$ \\
\hline \multirow{5}{*}{ G_2010 } & Frequency (F) & 15 & 39 & 36 & 74 & 45 & 0 & 0 \\
\hline & $\begin{array}{l}\text { Frequency - Percent } \\
\text { (\%) }\end{array}$ & 7.1 & 18.7 & 17.2 & 35.4 & 21.5 & 0 & 0 \\
\hline & $\begin{array}{l}\text { Cumulative frequency } \\
\text { (cf) }\end{array}$ & 15 & 54 & 90 & 164 & 209 & & \\
\hline & $\begin{array}{l}\text { Median class interval } \\
\text { - median }\end{array}$ & & & & 254.4 & & & \\
\hline & $\begin{array}{l}\text { Modal class interval } \\
\text { - mode }\end{array}$ & & & & 278.4 & & & \\
\hline \multirow{5}{*}{ G_2013 } & Frequency (F) & 28 & 28 & 43 & 58 & 14 & 8 & 31 \\
\hline & $\begin{array}{l}\text { Frequency - Percent } \\
\text { (\%) }\end{array}$ & 13.3 & 13.3 & 20.5 & 27.6 & 6.7 & 3.8 & 14.8 \\
\hline & $\begin{array}{l}\text { Cumulative frequency } \\
\text { (cf) }\end{array}$ & 28 & 56 & 99 & 157 & 171 & 179 & 210 \\
\hline & $\begin{array}{l}\text { Median class interval } \\
\text { - median }\end{array}$ & & & & 256.2 & & & \\
\hline & $\begin{array}{l}\text { Modal class interval } \\
\text { - mode }\end{array}$ & & & & 263.7 & & & \\
\hline
\end{tabular}

Table 7. Monthly household expenses per person

\begin{tabular}{|c|c|c|c|c|c|c|c|c|}
\hline & Class interval (PLN) & $\begin{array}{c}200- \\
300\end{array}$ & $\begin{array}{c}301- \\
400\end{array}$ & $\begin{array}{c}401- \\
500\end{array}$ & $\begin{array}{c}501- \\
600\end{array}$ & $\begin{array}{c}601- \\
700\end{array}$ & $\begin{array}{c}701- \\
800\end{array}$ & $>800$ \\
\hline \multirow{5}{*}{ G_2010 } & Frequency (F) & 23 & 36 & 98 & 25 & 15 & 12 & 0 \\
\hline & $\begin{array}{l}\text { Frequency - Percent } \\
\text { (\%) }\end{array}$ & 11.0 & 17.2 & 46.9 & 12.0 & 7.1 & 5.7 & 0 \\
\hline & $\begin{array}{l}\text { Cumulative } \\
\text { frequency (cf) }\end{array}$ & 23 & 59 & 157 & 182 & 197 & 209 & \\
\hline & $\begin{array}{l}\text { Median class interval } \\
\text { - median }\end{array}$ & & & 429.0 & & & & \\
\hline & $\begin{array}{l}\text { Modal class interval } \\
\text { - mode }\end{array}$ & & & 445.9 & & & & \\
\hline \multirow{5}{*}{ G_2013 } & Frequency (F) & 59 & 39 & 49 & 33 & 13 & 7 & 10 \\
\hline & $\begin{array}{l}\text { Frequency - Percent } \\
\text { (\%) }\end{array}$ & 28.1 & 18.6 & 23.3 & 15.7 & 6.2 & 3.3 & 4.8 \\
\hline & $\begin{array}{l}\text { Cumulative } \\
\text { frequency (cf) }\end{array}$ & 59 & 98 & 147 & 180 & 193 & 200 & 210 \\
\hline & $\begin{array}{l}\text { Median class interval } \\
\text { - median }\end{array}$ & & & 415.3 & & & & \\
\hline & $\begin{array}{l}\text { Modal class interval - } \\
\text { mode }\left(^{*}\right)\end{array}$ & 274.7 & & 439.5 & & & & \\
\hline
\end{tabular}

(*) - bimodal distribution

The data from table 5-7 enable calculation of the proportion of medians concerning monthly expenditures (Tab. 8).

Table 8. Proportions of medians

\begin{tabular}{lcc}
\hline & \multicolumn{2}{c}{ Groups } \\
\hline Proportions of medians $[\mathrm{PLN}] /[\mathrm{PLN}]$ & G_2010 & G_2013 \\
\hline Monthly medication expenses - median & 141/429=0.329 & $163.4 / 415.3=0.393$
\end{tabular}

Monthly medication expenses - median Monthly food expenses - median

$141 / 254.4=0.554 \quad 163.4 / 256.2=0.638$

The proportions calculated in Table 8 suggest the significant share of expenditure on medications in the household budget. Comparison of data obtained in 2010 and in 2013 suggests that over the years the situation has not improved, but somehow seems to be even worse. The differences between proportions suggest an unfavourable trend that requires further monitoring. 


\section{DISCUSSION}

Health care costs in Poland are high. The roots of this problem are many, varied and complicated. The most important factors may be named as [15]:

- low national health care expenditures per capita;

- low national income;

- low purchasing power of people (patients);

- lack of competition in the health insurance market.

It is obvious that the best health situations exist in countries that can allocate the largest sums to health care. In 2010, the USA had the highest health spending in the world equivalent to $17.9 \%$ of its gross domestic product (GDP), or $\$ 8,362$ per person [16]. At that time, most of the countries of Western and Northern Europe had expenditure in excess of $\$ 3,000$ (e.g. Denmark - \$3,861, Norway - $\$ 4,552$, Germany - \$3,339, France - \$3,130, Belgium - \$3,008, Netherlands - $\$ 3,991$, Sweden - $\$ 3,047)$. In 2010, health spending in Poland was close to $\$ 1072$ and was almost 3 times lower than spending in Switzerland $(\$ 3,184)$ and 1.5 times lower than spending in Greece [16]. Such an unfavourable situation of Polish health service is determined by a low national income and low percentage of the GDP allotted to the health care system. In Poland, 7.5\% of the GDP is allotted to health care, in Germany - 11.6\%, in France - 11.9, in Greece - $10.2 \%$ and in Slovakia $-8.8 \%$. Low expenditure on the health service in Poland is the reason for the lack of funds for the drug refund programme in that country. Although the official as well as bulk prices of medicines, compared to the European average prices, are rather low, the drug refund programme regulations result in the fact that for some patients, for financial reasons, drugs are too expensive and not available.

In the first quarter of 2011, despite the reimbursement for medical expenses, prices of medicines paid by the patients exceeded $50 \%$ of their true costs. As a result of a new Reimbursement Act published in 2012, there has been an increase in patient co-payments for prescription drugs (reimbursed and not refunded in total) up by 5.2 percentage points (from $52.5 \%$ to $57.7 \%$ ), and reimbursed up by 3.9 percentage points (from $34 \%$ in 2011 to $37.9 \%$ in 2012). Such high co-payment for drugs, in comparison to many other European countries, makes the drug policy in Poland the least friendly to the patient, and ambulatory treatment is relatively the most expensive.

In 2013, the patient's co-payment for generic drugs reimbursed will reach $39.6 \%$, and for innovative drugs $35.3 \%$ of their market value. This will be the highest level co-payments in the European Union [17]. For example, in Slovakia, the Czech Republic, and Hungary, it is 2-3 times lower than in Poland, where it is close to $13 \%$ [18].

According to the WHO analysis, co-payment for drugs that exceeds $40 \%$ of their market value, threatens the safety of pharmacotherapy and adversely affects patient medication adherence (in Poland, in 2012 average co-payments for all kinds of prescription drugs was equal to $57.7 \%$ ). Such aspects, as well as the poverty that affects the country (it influences on low purchasing power of people) are factors favouring the appearance of the phenomenon or medication nonadherence.

Poverty in Poland is a real problem. In the Lublin Province in 2011, $10.9 \%$ of inhabitants lived below subsistence level, $23.1 \%$ below the relative poverty line, and $10.2 \%$ below the legal poverty line. At his time, percentages concerning all Polish households were as follows: $6.7 \%$ of people lived below subsistence level, $16.7 \%$ below the relative poverty line, and $6.5 \%$ below the legal poverty line. The Lublin Province is one of the poorest region in the country; in 2009, the average pension from outside the KRUS system (The Agricultural Social Insurance Fund) in Lublin Province was equal to 1,140.18 PLN, from the KRUS system - 902.71 PLN, and the average pension due to disability - 1,074.37 PLN [19]. In 2011, the average pension from outside the KRUS was close to 1,475 PLN, and from the KRUS system - 979 PLN [20]. In 2012, in Lublin Province the average pension for incapacity for work was close to 793 PLN and a survivor's pension - 1,080 PLN. It must be emphasised that in this Province the average monthly disposable personal income is much less than the average personal income. This results from the real and hidden unemployment (many people with personal income support unemployed family members). This data, confronted with the declared monthly expenditure on drugs, housing and food (Tab. 5, 6, 7), suggest the possibility of the appearances of deficits in household budgets. The lack of funds necessitates borrowing money or making saving decisions. In the latter case, the question usually arises: reduce expenditures on the household, food, or medicines?

In 2011, the average co-payments for refunded medicines amounted to PLN 9.27, in 2013-9.82 PLN per one packet// bottle of medication. The schemes for treating many diseases require drugs that are non-refundable in Poland, where many anti-inflammatory, anti-hypertensive, anti-osteoporotic and neurological medicines are already at full price. This means that a patient who needs multidrug-treatment spends even 200-300 PLN (or more) monthly on drugs (200 PLN - this sum is equal to one fifth of an average pension from outside the KRUS system [20]). Observations by the authors of the presented study confirm that these calculations reflect the facts.

In 2013, monthly medication costs per person were distributed according to the e following data median value - 163.4 PLN (in 2010 141.0 PLN), modal values (96.5 PLN and 265.9 PLN - bimodal distribution) (Tab. 5).

While comparing proportions of medians: (monthly medication expenses)/(monthly household expenses) and (monthly medication expenses)/(monthly food expenses) describing the situations in 2010 and in 2013, the following conclusion can be drawn: medication expenses are high and their share in the structure of spending increases. This may foretell an increase in the number of cases of willful treatment modification in order to achieve savings, resulting in the deterioration in the results of ambulatory treatment.

The tendency to cutting back on costs of treatment realized by the poorest patients may be observed worldwide $[21,22$, $23,24]$. even in such industrialized countries as the USA [25]. And all over the world attempts have been made to improve the situation, and thus enhance the effectiveness of outpatient treatment. There are several good ideas implemented in different countries. Among them [13]:

- a tax relief program for the elderly and disabled;

- tax relief for the chronically ill;

- free drug coupons;

- financial support for the poor;

- financial support for members of poor families;

- controlled distribution of free drugs to patients suffering from selected diseases (usually diseases posing a significant 
threat to other people - such as leprosy, AIDS and tuberculosis).

In 2011, the authors published the suggestion that free drug coupons should be distributed to the poor or to members of families with a low income [13]. Nowadays, such an idea still seems to be realistic; however, this form of financial aid does guarantee that it will be used as intended, and only by people facing hard financial difficulties.

Due to the importance of the problem, the study will be continued.

\section{CONCLUSIONS}

1. In 2013, most of surveyed patients (54.8\%) did not follow prescribed treatment plans (in 2010-43.1\%).

2. In most cases, medication non-adherence resulted from financial problems.

3. In 2010, $12 \%$ of respondents expressed the opinion that they had always had enough means to buy necessary drugs (in 2013 - only $1.5 \%$ ).

4. Current regulations of medicines costs refunds may make effective ambulatory treatment of chronic diseases impossible.

5. It seems advisable to create effective mechanisms to ensure financial assistance to chronically ill people requiring long-lasting outpatient treatment.

\section{REFERENCES}

1. Sabaté E (ed.). Adherence to Long-Term Therapies: Evidence for Action. Geneva, Switzerland: World Health Organization; 2003.

2. van Eijken M, Tsang S, Wensing M, de Smet PA, Grol RP. Interventions to improve medication compliance in older patients living in the community: a systematic review of the literature. Drugs Aging. 2003; 20: $229-240$

3. Sankar UV, Lipska K, Mini GK, Sarma PS, Thankappan KR. The Adherence to Medications in Diabetic Patients in Rural Kerala, India. Asia Pac J Public Health. 2015; 27(2): NP513-23. doi: $10.1177 / 1010539513475651$.

4. Talam NC, Gatongi PM, Rotich JK, Kimaiyo S. Adherence to antiretroviral drug therapy by adult patients attending HIV/AIDS clinic at a Kenyan tertiary health institution. East Afr Med. J. 2009; 86(5): 240-243.

5. Mahfouz EM, Awadalla HI. Compliance to diabetes self-management in rural El-Mina, Egypt. Cent Eur J Public Health. 2011; 19(1): 35-41.

6. Farooq S, Nazar Z, Irfan M, Akhter J, Gul E, Irfan U, et al. Schizophrenia medication adherence in a resource-poor setting: randomised controlled trial of supervised treatment in out-patients for schizophrenia (STOPS). Br J Psychiatry. 2011; 199(6): 467-472.
7. Kronish IM, Diefenbach MA, Edmondson DE, Phillips LA, Fei K, Horowitz CR. Key barriers to medication adherence in survivors of strokes and transient ischemic attacks. J Gen Intern Med. 2013; 28(5): 675-682.

8. Atreja A, Bellam N, Levy S. Strategies to enhance patient adherence: Making it simple. Medacapt Gen Med. 2005; 7(1): 4.

9. American Pharmacists Association. Medication ComplianceAdherence-Persistence Digest. 2004; 7(4): 1-12.

10. Lau DT, Nau DP. Oral antihyperglycemic medication nonadherence and subsequent hospitalization among individuals with type 2 diabetes. Diabetes Care. 2004; 27(9): 2149-2153.

11. GUS. Stopa bezrobocia w latach 1990-2013 (bezrobocie rejestrowane). Główny Urząd Statystyczny. http://www.stat.gov.pl/gus/5840_677_ PLK_HTML.htm (access: 26.07.2013) (in Polish).

12. GUS. Sytuacja gospodarstw domowych w 2012 r. w świetle wyników badania budżetów gospodarstw domowych. Główny Urząd Statystyczny. Departament Badań Społecznych i Warunków Życia. Materiał na konferencję prasową w dniu 29 maja 2013. Poland, Warsaw, 2013 (in Poland).

13. Sygit K, Kołłątaj W, Sygit M, Kołłątaj B. The impact of economic factors on the realities of outpatient multi-drug treatment of chronic diseases in rural areas. Ann Agric Environ Med. 2011; 18(1): 29-34.

14. Preacher KJ. Calculation for the chi-square test: An interactive calculation tool for chi-square tests of goodness of fit and independence. 2001. http://quantpsy.org (access: 2013.09.03).

15. Magda I, Szczygielski K. Ocena możliwości poprawy działania polskiego system ochrony zdrowia. Współpłacenie i prywatne ubezpieczenia zdrowotne. Program. Ernst \& Young Sprawne Państwo. Warszawa, 2011 (in Polish)

16. WHO. Global Health Observatory Data Repository. World Health Statistics. http://apps.who.int/gho/data/node.main.1?lang=en. (access 26.07.2013).

17. IMS Health o listopadowej liście leków refundowanych. IMS Health/ Rynek Zdrowia. 06-11-2012 12:30 http://www.rynekzdrowia. pl/Farmacja/IMS-Health-o-listopadowej-liscie-lekowrefundowanych,124980,6,drukuj.html (access 28.06.2013) (in Polish).

18. Refundacja leków. Nazdrowie.pl http://www.nazdrowie.pl/artykul/ refundacja-lekow (access: 28.06.2013) (in Polish).

19. GUS. Gospodarstwa domowe dochody i wydatki w 2009 roku. GUS Lublin, 2010 (in Polish).

20. Markowski K (ed.). Rocznik statystyczny województwa lubelskiego. Statistical yearbook of the Lubelskie Voivodship.2012. Urząd Statystyczny w Lublinie. Lublin, 2012 (in Polish).

21. Montgomery MR. Urban Poverty and Health in Developing Countries. Popul Bull. 2009; 64: 1-20.

22. Rodrigues IL, Monteiro LL, Pacheco RH, da Silva SE. Abandonment of tuberculosis treatment among patients co-infected with TB/HIV. Rev Esc Enferm USP. 2010; 44: 383-387.

23. Widjanarko B, Gompelman M, Dijkers M, van der Werf MJ. Factors that influence treatment adherence of tuberculosis patients living in Java, Indonesia. Patient Prefer Adherence. 2009; 3: 231-238.

24. Das K, Ghosh M, Khanna B, Banerjee M, Mondal GP, Singh OP, et al. Discontinuation of secondary preventive treatment of stroke: An unexplored scenario in India. ClinNeurolNeurosurg. 2010; 112: 766769.

25. Hershman DL, Kushi LH, Shao T, Buono D, Kershenbaum A, Tsai WY, et al. Early discontinuation and non-adherence to adjuvant hormonal therapy are associated with increased mortality in women with breast cancer. J ClinOncol. 2010; 28: 4120-4128. 